\title{
Bronchial asthma and acid reflux into the distal and proximal oesophagus
}

\author{
P M Gustafsson, N-I M Kjellman, L Tibbling
}

\begin{abstract}
The prevalence of pathological gastrooesophageal reflux in children and adolescents with asthma was studied by 24 hour two level oesophageal pH monitoring in 42 subjects aged 9-20 years with moderate or severe bronchial asthma. The importance of oesophagobronchial nerve reflexes and of aspiration of gastric acid as triggers in asthma was assessed by studying whether episodes of reflux into the distal and into the proximal oesophagus were followed by asthma attacks. Twenty one subjects $(50 \%)$ had a pathological total reflux time in the distal oesophagus and six $(16 \%)$ in the proximal oesophagus. Nine patients had pathological gastro-oesophageal reflux into the distal oesophagus together with symptoms of asthma during the day on which the recording took place. In three of them the episodes of asthma symptoms were significantly correlated with preceding episodes of reflux into the distal oesophagus, and in one subject to reflux into the proximal oesophagus.

We conclude that pathological gastrooesophageal reflux is common in children and adolescents with asthma, but it seems to provoke symptoms of asthma in only a few. Symptoms of asthma were more often elicited by exposure of the distal oesophagus to gastric acid, possibly by a vagal reflex, than by aspiration of gastric juice.
\end{abstract}

Several studies have indicated that there is an association between gastro-oesophageal reflux and bronchial asthma in adults ${ }^{1-4}$ and in children. . $^{5}$ Oesophageal dysfunction is common in asthmatic children and adolescents, but the prevalence of pathological gastrooesophageal reflux is unknown.

Antireflux operations have been reported to improve asthma in subjects with severe gastrooesophageal reflux..$^{10-12}$ Aspiration of large amounts of gastric contents can provoke severe asthma attacks, but this is probably rare. ${ }^{13}$ Microaspiration of gastric juice has been suggested as a more frequent trigger in asthma. ${ }^{14}$ Bronchospasm might also be caused by an oesophagobronchial nerve reflex that is elicited when the distal oesophagus is exposed to gastric acid. ${ }^{15} 16$ The aspiration hypothesis would be supported if reflux into the proximal part of the oesophagus is shown to be followed by an attack of asthma.

Long term $\mathrm{pH}$ recording in the oesophagus is the most valid method of studying gastrooesophageal reflux. ${ }^{17-19}$ The aims of this inves- tigation were therefore to find out the prevalence of pathological gastro-oesophageal reflux in children and adolescents with asthma by 24 hour oesophageal pH monitoring, and to study the correlation between symptoms of asthma and reflux into the distal and proximal oesophagus.

\section{Patients and methods}

Forty two children and adolescents ( 25 boys and 17 girls with a mean age of 13.7 years, range $9 \cdot 0-20 \cdot 0$ ) with moderate or severe asthma attending the paediatric allergy clinic were investigated by 24 hour two level $\mathrm{pH}$ monitoring in the oesophagus. They had all previously undergone oesophageal manometry. All patients had bronchial asthma severe enough to restrict daily activities for a total of at least 10 days during the previous year despite treatment. Eighteen patients had had symptoms of asthma during at least 100 nights or mornings during the previous 12 months.

Thirty five of the 42 subjects had atopic asthma - that is, an allergy mediated by IgEaccording to the history and previous medical records. Twenty five participants $(60 \%)$ had a diagnosis of oesophageal dysfunction made on manometric findings that were reported in a previous study. ${ }^{9}$ Fourteen patients $(33 \%)$ had a history of oesophageal symptoms; 13 reported acid regurgitation, seven had heartburn, and two dysphagia. None had oesophageal symptoms that required regular or current antireflux treatment.

All subjects were receiving regular treatment for their asthma. At the time of investigation oral theophylline was being taken by 23 , oral $\beta_{2}$ adrenoreceptor stimulants by 20 , inhaled $\beta_{2}$ adrenoreceptor stimulants by 39 , sodium cromoglycate by 19 , inhaled corticosteroids by 12 , and oral corticosteroids by two.

\section{HOUR pH TEST}

For the 24 hour pH test a catheter assembly with two antimony $\mathrm{pH}$ electrodes was positioned with the electrodes 5 and $15 \mathrm{~cm}$ above the lower oesophageal sphincter. Perfused catheters with outlets $1 \mathrm{~cm}$ above each electrode and connected to pressure transducers permitted exact localisation of the $\mathrm{pH}$ probe by manometry. The catheter outlets also allowed calibration of the $\mathrm{pH}$ electrodes when they were in place. The overall diameter of the assembly was $3 \mathrm{~mm}$. The catheter assembly was passed through the nose into the stomach. The probe was then withdrawn into the distal oesophagus 
and the electrodes were positioned with the participant supine. A reference electrode was attached to the chest. The $\mathrm{pH}$ electrodes and the reference electrode were connected to two battery operated $\mathrm{pH}$ meters, one for each level, and the $\mathrm{pH}$ signals were recorded on a portable four channel tape recorder (Oxford Medilog). The equipment was placed in a small shoulder bag so that the patients could walk freely about the ward. The electrodes were calibrated with solutions of $\mathrm{pH} \mathrm{7.0}$ and 1.6 four times during the 24 hour period. The participants were told not to lie down during the day. During the monitoring period the subjects stayed on the paediatric ward and had a special acid free diet ( $\mathrm{pH}>5$ ) consisting of four meals. The only intake allowed between meals was medication and water. Coffee and acid drinks were not allowed. The patients took their normal treatment for asthma on the day of recording and inhaled $\beta_{2}$ adrenoreceptor stimulants when required.

The $\mathrm{pH}$ recordings were played back on a strip chart. A drop in $\mathrm{pH}$ to 4 or below was regarded as evidence of reflux. The percentage reflux time, the number of reflux episodes/ hour, and the duration of the longest reflux episode were calculated.

In a previous study on healthy children and adolescents (14 boys and 13 girls $9 \cdot 3$ to $17 \cdot 3$ years of age, mean age $13 \cdot 1$ years) normal values of gastro-oesophageal reflux were evaluated by the same technique and strict standardisation as in the present investigation. ${ }^{20}$ The upper limits of the reference ranges were defined as the upper 95th centile of percentage reflux time. Normal upper limits in the distal oesophagus were $1.0 \%$ (total reflux time), $2.0 \%$ (upright reflux time), and $0.9 \%$ (supine reflux time). In the proximal oesophagus the limits were $0.6 \%$ (total reflux time), $\mathbf{0 . 7 \%}$ (upright reflux time), and $0.8 \%$ (supine reflux time). ${ }^{20}$

Because of disconnection of the electric cable from the proximal $\mathrm{pH}$ electrodes, recordings from the proximal oesophagus were not obtained in five cases.
Peak expiratory flow rate (PEFR) was checked with a Mini Wright Peak Flow Meter every hour while the patients were awake. The highest value of three was recorded on each occasion and related to the predicted PEFR. ${ }^{21}$ The patients were given a form on which they recorded symptoms of asthma (breathlessness, wheezing, or attacks of cough), and symptoms of reflux (acid regurgitation and heartburn) and the drugs they were taking. 'Morning dipping' was defined as a decrease in the morning PEFR value by more than $20 \%$ of the mean of the other PEFR recordings.

When the association between reflux and symptoms of asthma was analysed, only reflux episodes in the distal oesophagus that lasted for at least one minute, and any episode in the proximal oesophagus that occurred within 30 minutes before the respiratory event, were considered.

\section{STATISTICAL ANALYSIS}

For statistical analysis the two tailed MannWhitney $U$ test, the Fisher's exact test, the $\chi^{2}$ test, and regression analysis were used. A $p$ value of $<0.05$ was regarded as significant.

\section{ETHICS}

The study was approved by the ethics committee for human research at the University Hospital, Linköping, and written consent was obtained from the participants or their parents.

\section{Results}

The total reflux time was significantly longer in the patients with asthma than in control subjects $(p<0.001$, table 1$)$. Twenty one of the 42 asthmatic children and adolescents $(50 \%)$ had a pathological total reflux time $(>1.0 \%)$ in the distal oesophagus. Twenty five patients $(60 \%)$ had pathological reflux into the distal oesophagus either throughout the 24 hour period $(n=21)$, or in the upright $(n=15)$, or the supine position $(n=18)$. Altogether $16 \%$ of the patients had patho-

Table 1 Twenty four hour two level pH monitoring in the oesophagus in 42 patients with asthma and 27 control subjects

\begin{tabular}{|c|c|c|c|c|c|c|}
\hline \multirow[t]{2}{*}{24 hour $\mathrm{pH}$ monitoring } & \multicolumn{2}{|l|}{$\begin{array}{l}\text { Percentage } \\
\text { reflux time }\end{array}$} & \multicolumn{2}{|c|}{$\begin{array}{l}\text { No of episodes of } \\
\text { reflux/hour }\end{array}$} & \multicolumn{2}{|c|}{$\begin{array}{l}\text { Duration of longest episode of } \\
\text { reflux (min) }\end{array}$} \\
\hline & $\begin{array}{l}\text { Asthmatic } \\
\text { patients }\end{array}$ & $\begin{array}{l}\text { Control } \\
\text { subjects }\end{array}$ & $\begin{array}{l}\text { Asthmatic } \\
\text { patients }\end{array}$ & $\begin{array}{l}\text { Control } \\
\text { subjects }\end{array}$ & $\begin{array}{l}\text { Asthmatic } \\
\text { patients }\end{array}$ & $\begin{array}{l}\text { Control } \\
\text { subjects }\end{array}$ \\
\hline $\begin{array}{l}\text { Total period } \\
\text { Distal oesophagus: } \\
\text { Mean (SD) } \\
\text { Range }\end{array}$ & $\begin{array}{l}1 \cdot 52(1 \cdot 42)^{* * *} \\
0 \cdot 0-5 \cdot 3\end{array}$ & $\begin{array}{l}0 \cdot 47(0 \cdot 39) \\
0 \cdot 0-1 \cdot 3\end{array}$ & $\begin{array}{l}0.95(0 \cdot 70)^{* * *} \\
0 \cdot 0-2 \cdot 1\end{array}$ & $\begin{array}{l}0 \cdot 43(0 \cdot 34) \\
0 \cdot 0-1 \cdot 3\end{array}$ & $\begin{array}{l}5 \cdot 03(7 \cdot 10)^{* *} \\
0 \cdot 0-8 \cdot 3\end{array}$ & $\begin{array}{l}1 \cdot 69(1 \cdot 22) \\
0.0-5 \cdot 0\end{array}$ \\
\hline $\begin{array}{l}\text { Proximal oesophagus: } \\
\text { Mean (SD) } \\
\text { Range }\end{array}$ & $\begin{array}{l}0 \cdot 34(0 \cdot 29)^{* *} \\
0 \cdot 0-1 \cdot 3\end{array}$ & $\begin{array}{l}0 \cdot 13(0 \cdot 17) \\
0 \cdot 0-0 \cdot 6\end{array}$ & $\begin{array}{l}0 \cdot 29(0 \cdot 27)^{*} \\
0 \cdot 0-1 \cdot 0\end{array}$ & $\begin{array}{l}0 \cdot 15(0 \cdot 20) \\
0 \cdot 0-0 \cdot 8\end{array}$ & $\begin{array}{l}1 \cdot 39(1 \cdot 09)^{* *} \\
0 \cdot 0-3 \cdot 5\end{array}$ & $\begin{array}{l}0 \cdot 72(0 \cdot 97) \\
0 \cdot 0-3 \cdot 3\end{array}$ \\
\hline $\begin{array}{l}\text { Upright position } \\
\text { Distal oesophagus } \\
\text { Mean (SD) } \\
\text { Range }\end{array}$ & $\begin{array}{l}1 \cdot 82(1 \cdot 90)^{*} \\
0 \cdot 0-7 \cdot 5\end{array}$ & $\begin{array}{l}0 \cdot 79(0 \cdot 73) \\
0 \cdot 0-2 \cdot 7\end{array}$ & $\begin{array}{l}1.30(1.04)^{*} \\
0.0-3.9\end{array}$ & $\begin{array}{l}0 \cdot 76(0 \cdot 68) \\
0 \cdot 0-2 \cdot 7\end{array}$ & $\begin{array}{l}2 \cdot 69(3 \cdot 56) \\
0 \cdot 0-6 \cdot 3\end{array}$ & $\begin{array}{l}1.43(1.20) \\
0.0-5 \cdot 0\end{array}$ \\
\hline $\begin{array}{l}\text { Proximal oesophagus } \\
\text { Mean (SD) } \\
\text { Range }\end{array}$ & $\begin{array}{l}0 \cdot 36(0 \cdot 44) \\
0 \cdot 0-1 \cdot 5\end{array}$ & $\begin{array}{l}0 \cdot 18(0 \cdot 29) \\
0 \cdot 0-1 \cdot 2\end{array}$ & $\begin{array}{l}0 \cdot 36(0 \cdot 50) \\
0 \cdot 0-2 \cdot 6\end{array}$ & $\begin{array}{l}0 \cdot 28(0 \cdot 40) \\
0 \cdot 0-1 \cdot 7\end{array}$ & $\begin{array}{l}0.95(1.05)^{*} \\
0.0-3.5\end{array}$ & $\begin{array}{l}0.42(0.57) \\
0.0-2 \cdot 3\end{array}$ \\
\hline $\begin{array}{l}\text { Supine position } \\
\text { Distal oesophagus } \\
\text { Mean (SD) } \\
\text { Range }\end{array}$ & $\begin{array}{l}1 \cdot 18(1 \cdot 46)^{* * *} \\
0 \cdot 0-6 \cdot 1\end{array}$ & $\begin{array}{l}0 \cdot 17(0 \cdot 33) \\
0 \cdot 0-1 \cdot 4\end{array}$ & $\begin{array}{l}0.56(0.59)^{* * *} \\
0.0-2 \cdot 6\end{array}$ & $\begin{array}{l}0 \cdot 08(0 \cdot 11) \\
0 \cdot 0-2 \cdot 4\end{array}$ & $\begin{array}{l}3 \cdot 70(6 \cdot 82)^{* * *} \\
0 \cdot 0-8 \cdot 3\end{array}$ & $\begin{array}{l}0 \cdot 62(1 \cdot 01) \\
0 \cdot 0-3 \cdot 5\end{array}$ \\
\hline $\begin{array}{l}\text { Proximal oesophagus } \\
\text { Mean (SD) } \\
\text { Range }\end{array}$ & $\begin{array}{l}0.29(0.47)^{*} \\
0.0-1.9\end{array}$ & $\begin{array}{l}0 \cdot 10(0 \cdot 30) \\
0 \cdot 0-1 \cdot 3\end{array}$ & $\begin{array}{l}0.22(0.38)^{*} \\
0.0-1.5\end{array}$ & $\begin{array}{l}0.03(0.08) \\
0.0-0 \cdot 4\end{array}$ & $\begin{array}{l}0.69(0.91)^{*} \\
0.0-2.5\end{array}$ & $\begin{array}{l}0.37(0.94) \\
0 \cdot 0-3 \cdot 3\end{array}$ \\
\hline
\end{tabular}


Table 2 Details of nine patients with gastro-oesophageal reflux together with symptoms of asthma during the period of recording

\begin{tabular}{|c|c|c|c|c|c|c|c|c|c|c|}
\hline & \multicolumn{9}{|l|}{ Case No } & \multirow[t]{2}{*}{ Total } \\
\hline & 1 & 2 & 3 & 4 & 5 & 6 & 7 & 8 & 9 & \\
\hline \multirow{4}{*}{$\begin{array}{l}\text { Distal oesophagus } \\
\text { Total No of evaluated half hour periods } \\
\text { No (\%) with reflux into distal } \\
\text { oesophagus } \\
\text { Total No of episodes of asthma } \\
\text { No (\%) preceded by reflux into distal } \\
\text { oesophagus } \\
\text { Second proportion divided by first } \\
\text { proportiont }\end{array}$} & 47 & 46 & 45 & 44 & 46 & 46 & 46 & 46 & 42 & 408 \\
\hline & $10(21)$ & ${ }_{6}^{10}(22)$ & ${ }_{6}^{10}(22)$ & $14(32)$ & $\begin{array}{l}6(13) \\
1\end{array}$ & $3^{7(15)}$ & $11(24)$ & $\begin{array}{l}5(11) \\
1\end{array}$ & $3^{7(17)}$ & $\begin{array}{l}80(20) \\
31\end{array}$ \\
\hline & $4(100)$ & $3(50)$ & $5(83)$ & $5(100)$ & 0 & $1(33)$ & $1(50)$ & 0 & $2(67)$ & $21(68)$ \\
\hline & $4 \cdot 7^{* *}$ & $2 \cdot 3$ & $3 \cdot 8^{* *}$ & $3 \cdot 2^{* *}$ & 0 & $2 \cdot 2$ & $2 \cdot 1$ & 0 & 0 & $3 \cdot 4^{* * *}$ \\
\hline \multirow{4}{*}{$\begin{array}{l}\text { Proximal oesophagus } \\
\text { Total No of evaluated half hour periods } \\
\text { No (\%) with reflux into proximal } \\
\text { oesophagus } \\
\text { Total No of episodes of asthma } \\
\text { No (\%) preceded by reflux into } \\
\text { proximal oesophagus } \\
\text { Second proportion divided by first } \\
\text { proportiont }\end{array}$} & 47 & 46 & 45 & Not done & 46 & 46 & 46 & 46 & 46 & 368 \\
\hline & $\begin{array}{l}2(4) \\
4\end{array}$ & ${ }_{6}^{10}(22)$ & $\begin{array}{l}2(4) \\
6\end{array}$ & $\begin{array}{l}\text { Not done } \\
\text { Not done }\end{array}$ & $\begin{array}{l}8(17) \\
1\end{array}$ & ${ }_{3}^{6(13)}$ & $7^{7(15)}$ & $\begin{array}{l}3(7) \\
1\end{array}$ & $\begin{array}{l}7(15) \\
3\end{array}$ & $\begin{array}{l}45(12) \\
26\end{array}$ \\
\hline & $1(25)$ & $3(50)$ & $2(67)$ & Not done & $1(100)$ & $1(33)$ & $1(50)$ & 0 & $2(67)$ & $11(42)$ \\
\hline & 5.9 & $2 \cdot 3$ & $7 \cdot 5^{*}$ & Not done & $5 \cdot 8$ & $3 \cdot 3$ & $3 \cdot 3$ & 0 & 0 & $3 \cdot 5^{* * *}$ \\
\hline $\begin{array}{l}\text { Percentage total reflux time in distal } \\
\text { oesophagus }\end{array}$ & $2 \cdot 4$ & $2 \cdot 2$ & $5 \cdot 1$ & $4 \cdot 0$ & $2 \cdot 1$ & $2 \cdot 6$ & 4.4 & $1 \cdot 2$ & $1 \cdot 4$ & $2 \cdot 8$ \\
\hline
\end{tabular}

tOver-representation of asthmatic episodes preceded by reflux were compared by Fisher's exact test within subjects and by $\chi^{2}$ test for whole group.

\section{Discussion}

In this study we have shown that pathological gastro-oesophageal reflux was common in children and adolescents with bronchial asthma, and in a few patients gastro-oesophageal reflux seemed to provoke symptoms of asthma. The pathological reflux was moderately severe, and the findings could even be regarded as normal if compared with the reference limits of other studies on $\mathrm{pH}$ monitoring. ${ }^{22-26}$ Some of these studies can, however, be criticised for lack of standardisation, ${ }^{22-24}$ and for the inclusion of subjects who were not in good health. ${ }^{23-26}$ The reference range for percentage reflux time in children and adolescents referred to in our study were collected using strict criteria for normality. ${ }^{20}$ All control subjects were admitted to hospital during the $\mathrm{pH}$ monitoring and were given an acid free diet, and the $\mathrm{pH}$ electrodes were positioned exactly 5 and $15 \mathrm{~cm}$ above the lower oesophageal sphincter. ${ }^{20}$ Furthermore, the asthmatic patients in the present study and the control subjects were all investigated in the same laboratory. In healthy adults investigated in this laboratory the normal upper limit of the reference range for percentage total reflux time in the distal oesophagus was the same as in children-that is, $1.0 \% .^{27}$

A high incidence of pathological gastrooesophageal reflux was also found by Ekström in asthmatic adults. ${ }^{3}$ In his study, $60 \%$ of the patients had a pathological total reflux time $(>1 \cdot 0 \%)$. Reflux and asthma were, however, more severe and reflux symptoms were more common in the asthmatic adults than in the patients in the present study. On the other hand, only $10 \%$ of the adult asthmatic patients with pathological gastrooesophageal reflux had attacks of asthma associated with reflux ${ }^{28}$ which is consistent with our findings.

The correlation between attacks of asthma and reflux into the distal oesophagus was stronger than that between asthma and reflux into the proximal oesophagus. This suggests that aspiration may be a less frequent trigger of asthma than oesophagobronchial nerve reflexes in the patients investigated. The significant correlation between reflux and episodes of asthma in the present study should be viewed with some caution. Two unrelated phenomena can have a similar pattern of occurrence, due, for instance, to a tendency to clustering in time or in periods.

The 42 subjects in the present study were recruited from a group of 55 unselected patients with moderate or severe asthma. They had previously undergone oesophageal manometry in a 
study aimed at investigating the incidence of oesophageal dysfunction among asthmatic children and adolescents. ${ }^{9}$ The patients who declined to undergo 24 hour $\mathrm{pH}$ monitoring did not differ from the participants in the severity of their asthma, the findings at manometry, or the presence of oesophageal symptoms.

The coincidence of gastro-oesophageal reflux and asthma may have at least three explanations. Common aetiological denominators for asthma and gastro-oesophageal reflux-for example, autonomic disturbances and allergic reactions-could be one explanation. There is a high incidence of autonomic nervous system abnormalities among asthmatic subjects. ${ }^{29}$ Furthermore, most children with asthma have some IgE mediated allergy. As inhaled antiasthmatic drugs do, to a large extent $(90 \%)$, reach the gastrointestinal tract it is reasonable to believe that airborne allergens also reach the oesophagus and stomach. ${ }^{30}$ If allergic reactions take place in the upper gastrointestinal tract they might induce hypersecretion of gastric acid or dysfunction of the oesophagus and stomach, which in turn facilitate gastro-oesophageal reflux.

Another possible explanation is that asthma or drugs for its treatment cause pathological gastrooesophageal reflux. Ekström and Tibbling reported that reflux did not increase when bronchospasm was provoked in patients with asthma and gastro-oesophageal reflux disease ${ }^{31}$; on the other hand, oral theophylline increased gastrooesophageal reflux in the same patients. ${ }^{31}$ In the present study reflux time did not differ between those who did, and those who did not, take ora treatment for their asthma.

The third explanation is that gastro-oesophageal reflux may trigger asthmatic attacks. In spite of a high incidence of pathological gastro-oesophageal reflux in asthmatic subjects, however, reflux seems to provoke asthmatic symptoms in only a few of them. Wilson et al have reported that stimulation of the oesophagus by oral intake of cold or acid drinks can temporarily increase bronchial reactivity in asthmatic patients. ${ }^{32}$ In a similar fashion, asthmatic attacks might be more easily provoked by various extraoesophageal trigger factors as a result of increased bronchial reactivity when the oesophagus is exposed to gastric juice. Additional modulating factors like recumbency and sleep might further facilitate asthmatic attacks. Hence, oesophagobronchial reflex mechanisms may be more important in asthma than has been shown in the present study.

In conclusion, moderately severe pathological gastro-oesophageal reflux is a common finding in children and adolescents with asthma. In a few of them gastro-oesophageal reflux seems to provoke episodes of asthma, probably more often through oesophagobronchial nerve reflexes induced by the exposure of the distal oesophagus to gastric acid, than by aspiration.

This study was supported by a grant from the Swedish Medical Research Council, project No $17 \mathrm{X}-4260$.

1 Overholt RH, Voorhees RJ. Esophageal reflux as a trigger in asthma. Diseases of the Chest 1966;49:464-6.
2 Mays EE. Intrinsic asthma in adults. Association with gastroesophageal reflux. FAMA 1976;236:2626-8.

3 Ekström T. The importance of gastro-oesophageal reflux as a trigger factor in bronchial asthma. Linköping: Linköping University Medical Dissertations No 278, 1988.

4 Nagel RA, Brown P, Perks WH, Wilson RS, Kerr GD Ambulatory $\mathrm{pH}$ monitoring of gastro-oesophageal reflux in 'morning dipper' asthmatics. Br Med f $1988 ; 297: 1371-3$.

5 Shapiro GG, Christie DL. Gastroesophageal reflux in steroid dependent asthmatic youths. Pediatrics 1979;63:207-12.

6 Euler AR, Byrne WJ, Ament WE, et al. Recurrent pulmo nary disease in children: a complication of gastroesophageal reflux. Pediatrics 1979;63:57-61.

7 Danus O, Casar C, Larrain A, Pope CE II. Esophageal reflux-an unrecognized cause of recurrent obstructive bronchitis in children. $\mathcal{f}$ Pediatr 1976;89:220-4.

8 Martin ME, Grunstein MM, Larsen GL. The relationship of gastro-oesophageal reflux to nocturnal wheezing in children with asthma. Ann Allergy 1982;49:318-22.

9 Gustafsson PM, Kjellman N-I M, Tibbling L. Oesophagea function and symptoms in moderate and severe asthma. Acta Paediatr Scand 1986;75:729-36.

10 Fonkalsrud EW, Ament ME, Berquist W. Surgical management of gastroesophageal reflux syndrome in childhood. ment of gastroesophageal

11 Perrin-Fayolle M, Gormand F, Braillon G, et al. Long-term results of surgical treatment for gastroesophageal reflux in results of surgical treatment for gastroeso
asthmatic patients. Chest 1989;96:40-5.

12 Sontag S, O'Connel S, Greenlee H, et al. Is gastroesophageal reflux a factor in some asthmatics? Am $\mathcal{f}$ Gastroenterol 1987; 82:119-26.

13 Mendelson CL. The aspiration of stomach content into the lung during obstetric anaesthesia. Am $\mathcal{f}$ Obstet Gynecol 1946;52:191-205.

14 Boyle JT, Tuchman DN, Altschuler SM, Nixon TE Pach AL, Cohen S. Mechanisms for the association of gastroesophageal reflux and bronchospasm. Am Rev Respir Dis 1985;131(suppl):16-20.

15 Spaulding HS, Mansfield LE, Stein MR, Sellner JC, Gremillon DE. Further investigation of the relationship between gastroesophageal reflux and bronchoconstriction. f Allergy Clin Immunol 1982;69:516-21.

16 Davis RS, Larsen GL, Grunstein MM. Respiratory response to intraoesophageal acid infusion in asthmatic children to intraosophageal acid infusion in asthmatic children

17 Richter JE, Castell DO. Gastroesophageal reflux. Pathogenesis, diagnosis, therapy. Ann Intem Med 1982;97: 93-103.

18 Johansson K-E, Ask P, Tibbling L. Equipment design for 24-hr esophageal pH monitoring. In: DeMeester TR, Skinner DB, eds. Esophageal disorders: pathophysiology and therapy. New York: Raven Press, 1985:505-8.

19 Johansson K-E, Tibbling L. Evaluation of the 24-hour pH test at two different levels of the esophagus. In: DeMeester TR, Skinner DB, eds. Esophageal disorders: pathophysiology and therapy. New York: Raven Press, 1985:579-82.

20 Gustafsson PM, Tibbling L. 24-hour oesophageal two-level pH monitoring in healthy children. Scand $\mathcal{F}$ Gastroenterol 1988;23:91-4.

21 Solymar L, Aronsson P-H, Bake B, Bjure J. Nitrogen single breath test, flow volume curve and spirometry in healthy children, 7-18 years of age. Eur $\mathcal{f}$ Respir Dis 1980;61: 275-86.

22 Newman $L J$ Berezin $S$, San Filippo JA, Halata $M$, Medow MS, Schwarz SM. A new ambulatory system for Medow MS, Schwarz SM. A new ambulatory system for extended esophageal pH

23 Jolley SG, Johnson DG, Herbst JJ, Pena AR, Garnier RC. An assessment of gastroesophageal reflux in children by extended pH monitoring of the distal oesophagus. Surgery 1978;84:16-24.

24 Euler AR, Byrne WJ. Twenty-four hour esophageal intraluminal $\mathrm{pH}$ probe testing. A comparative analysis. Gastraenterology 1981;80:957-61.

25 DeMeester TR, Johnson LF, Joseph GJ, Toscano MS, Hall AW, Skinner DB. Patterns of gastroesophageal reflux in health and disease. Ann Surg 1976;184:459-70.

26 Arasu TS, Wyllie R, Fitzgerald JF, et al. Gastroesophageal reflux in infants and children-comparative accuracy of diagnostic methods. F Pediatr 1980;96:798-803.

27 Johansson K-E, Boeryd B, Fransson S-G, Tibbling L. Oesophageal reflux tests, manometry, endoscopy, biopsy and radiology in healthy subjects. Scand $\mathcal{J}$ Gastroenterol and radiology in

28 Ekström T, Tibbling L. Gastro-oesophageal reflux and triggering of bronchial asthma: a negative report. Eur triggering of bronchial asthm.

29 Kaliner M. Autonomic nervous system abnormalities and allergy. Ann Intern Med 1982;96:349-57.

30 Davies DS. Pharmacokinetics of inhaled substances. Postgrad Med $\mathcal{F}$ 1975;51(suppl 7):69-75.

31 Ekström T, Tibbling L. Can mild bronchospasm reduce gastroesophageal reflux? Am Rev Respir Dis 1989;139:52-5.

32 Wilson MM, Chudry N, Silverman M. Role of the oesophagus in asthma induced by the ingestion of ice and acid. gus in asthma induced
Thorax 1987;42:506-10. 